\title{
Analysis of the antigenic composition of liver specific lipoprotein using murine monoclonal antibodies
}

\author{
K H WIEDMANN, L K TREJDOSIEWICZ, A H GOODALL, AND H C THOMAS \\ From the Departments of Medicine and Immunology, Royal Free Hospital and Medical School, London
}

SUMmary Eight monoclonal antibodies have been raised to antigenic determinants within the liver specific lipoprotein complex. Five of these determinants were species and the others non-species specific. No liver specific determinants were identified. Liver specific lipoprotein antigens recognised by the eight monoclonal antibodies were located either on the hepatocyte membrane and/or along the sinusoidal lining wall or in the cytoplasm of liver parenchymal cells. All antibodies but one reacted with the cell membrane of viable human hepatocytes. The molecular weights of four liver specific lipoprotein-determinants were determined by immunoprecipitation. These ranged from 22000 to 164000 daltons.

Liver specific lipoprotein is a macrolipoprotein complex which is prepared from an homogenate of human liver by ultracentrifugation and gel filtration. ${ }^{1}$ Heterologous antisera raised against this complex bind to the surface of liver cells. ${ }^{2}$ This complex probably contains membrane derived lipids which have been partially characterised, and at least five major and several minor polypeptides. ${ }^{3}$ There are both species and non-species specific determinants within the complex. ${ }^{4}$ In addition, as well as the presumed liver specific determinants, there are also non-liver specific determinants. ${ }^{135}$

Cellular $^{6}$ and humoral ${ }^{78}$ immunity to this lipoprotein complex has been shown in patients with acute and chronic liver disease, and it is suggested that they are the cause of liver cell necrosis. ${ }^{9}$ Because liver specific lipoprotein preparations contain several antigenic determinants (non-liver as well as liver-specific determinants), the specificity of these immune reactions might also be heterogenous. Before their significance can be determined it is necessary to analyse the antigenic complexity of this lipoprotein in more detail. We have therefore raised monoclonal antibodies to liver specific lipoprotein and used these to purify and characterise some of the component determinants.

Address for correspondence: Dr H C Thomas, Department of Medicine, Royal Free Hospital and Medical School, Pond Street, London NW3.

Received for publication 27 June 1984

\section{Method}

PREPARATION OF LIVER SPECIFIC LIPOPROTEIN Liver specific lipoprotein was prepared at $4^{\circ} \mathrm{C}$ using fresh specimens from two kidney donors (one woman, 28 years and one man 36 years) according to the established procedure of McFarlane. ${ }^{3}$ Briefly, a liver homogenate $(50 \% \mathrm{w} / \mathrm{v})$ in $0.25 \mathrm{M}$ sucrose $(\mathrm{pH}$ 8.0 ) was prepared and centrifuged at $105000 \mathrm{~g}$ for 60 minutes. The supernatant was divided into $20 \mathrm{ml}$ aliquots and stored at $-20^{\circ} \mathrm{C}$ for up to eight months. A $20 \mathrm{ml}$ aliquot of the supernatant was applied to a sepharose 6B (Pharmacia) column, gel bed $58 \times 5$ $\mathrm{cm}$, and eluted with Tris- $\mathrm{HCl}$ buffer, $\mathrm{pH} 8.0$ containing $0.2 \mathrm{M} \mathrm{NaCl}, 1 \mathrm{mM}$ disodium-EDTA and $0.05 \%$ sodium azide. The void volume was concentrated using sucrose, and the protein content was measured according to Lowry. ${ }^{10}$ The total yield from $10 \mathrm{ml}$ of supernatant was $13-16 \mathrm{mg}$ liver specific lipoprotein within the various preparations. Liver specific lipoprotein was stored at $4^{\circ} \mathrm{C}$.

\section{IMMUNISATION}

Four Balb/c mice were immunised intraperitoneally with $50 \mu \mathrm{g}$ liver specific lipoprotein in complete Freunds adjuvant at time 0,4 , and 8 weeks. Mouse 1 was given an intravenous booster injection of $10 \mu \mathrm{g}$ liver specific lipoprotein immediately and mouse $2 \mathrm{a}$ booster injection after a further three months. Mice 3 and 4 were boosted intraperitoneally with $25 \mu \mathrm{g}$ liver specific lipoprotein and killed four weeks later after a final intravenous booster injection of 5-10 $\mu \mathrm{g}$ 
liver specific lipoprotein. Spleens were harvested three to four days later from anitbody producing mice. Three different liver specific lipoprotein preparations were used for the immunisation procedure.

PRODUCTION OF HYBRID CELL LINES

Fusions were performed by a modification of the method described by Galfré et al. ${ }^{11}$ Spleens of antibody producing animals were removed and mixed with myeloma cells (P3-NS1/1-Ag 4-1) in a ratio 10:1. The cell mixtures were pelleted at $200 \mathrm{~g}$ for five minutes and incubated with $1 \mathrm{ml}$ polyethylene glycol 1500 (BDH Chemicals Ltd) $(66.4 \% \mathrm{w} / \mathrm{v})$ for seven minutes at $37^{\circ} \mathrm{C}$. The fusion mixture was then gradually diluted by addition of small aliquots of RPMI 1640 (Flow). Finally the cells $\left(1 \times 10^{6}\right.$ cells $\left./ \mathrm{ml}\right)$ were dispensed in $2 \mathrm{ml}$ linbro trays (Flow). Twenty four hours later $1 \mathrm{ml} \mathrm{HAT}$ medium (RPMI 1640 containing $10 \%$ FCS, $2 \mathrm{mM}$ glutamine, $10^{-4} \mathrm{M}$ hypoxanthine, $4 \times 10^{-7} \mathrm{M}$ aminopterin, $1.6 \times 10^{-5} \mathrm{M}$ thymidine and antibiotics) was added to each well. Beginning between day 10 to 14 the medium from wells showing cell growth was tested for antibody activity. Those hybridomas secreting specific antibody were cloned by limiting dilution ( 1 cell/well) in microtitre plates with feeder layers of normal spleen cells.

The monoclonal antibodies obtained from culture fluid in which the cells had been growing or from ascitic tumours in mice were purified by absorption onto a protein $\mathrm{A}$-sepharose $\mathrm{Cl}-4 \mathrm{~B}$ column (Pharmacia) eluting with $\mathrm{pH} 5.5$ citrate buffer $(0 \cdot 1$ $\mathrm{mol} / \mathrm{l}$ citric acid, $0.1 \mathrm{~mol} / \mathrm{l}$ disodium hydrogen phosphate).

DETERMINATION OF IMMUNOGLOBULIN CLASS OF MONOCLONAL ANTIBODIES

The immunoglobulin class of each monoclonal antibody was determined by double diffusion in $1 \%$ agar gels (in Barbitone buffer $\mathrm{pH}$ 8.2) using immunoglobulin subclass specific antisera (Meloy).

BLOCKING EXPERIMENTS WITH MONOCLONAL ANTIBODIES

Monoclonal antibodies were used radiolabelled and unlabelled in blocking experiments to define their epitope specificity. Liver specific lipoprotein $0.5 \mu \mathrm{g}$ and $100000 \mathrm{cpm}(100 \mu \mathrm{l})$ of radiolabelled antibody (incubation at $4^{\circ} \mathrm{C}$ for one hour) was found to be the optimum condition in this study. The blocking reagents were added in excess starting with $100 \mu$ l of $2 \mathrm{mg} / \mathrm{ml}$ antibody and diluting them out to $1 / 1000$. Washing procedures were carried out with phosphate buffered saline, $\mathrm{pH} 7 \cdot 2$ with $1 \%$ BSA and $0.05 \%$ sodium azide. All experiments were carried out in a reciprocal fashion - that is, each antibody was used 'cold' and 'hot'. The monoclonal antibody RF-HBs- $1^{12}$ was included as control.

RADIOMETRIC BINDING ASSAY FOR ANTI-LIVER SPECIFIC LIPOPROTEIN ANTIBODIES IN MOUSE SERA AND CULTURE SUPERNATANT

Polystyrene microtitre plates were coated with $1 \mu \mathrm{g}$ liver specific lipoprotein/well (preparation used for immunisation and one freshly prepared batch) in $0 \cdot 1$ $\mathrm{M}$ Tris $\mathrm{HCl}$ buffer $\mathrm{pH} 8$, overnight at $+4^{\circ} \mathrm{C}$. After coating the free binding sites with $1 \% \mathrm{BSA}$ in Tris $\mathrm{HCl}$ buffer (two to four hours) test samples were added for four hours at room temperature. Mouse sera were diluted up to $1 / 10000$, and culture supernatants were used neat or adjusted to $5 \mu \mathrm{g} / \mathrm{ml}$ antibody. The wells were then washed with Tris buffer and $\mathrm{I}^{125}$ goat anti-mouse immunoglobulin $(100000 \mathrm{cpm} /$ well $)$ was added for two hours. After three washes with PBS the plates were cut with scissors and the single wells counted in a gamma counter.

\section{IMMUNOFLUORESCENCE TEST ON TISSUE} SECTIONS

Tissue sections (4-6 $\mu$ thick) were fixed in chloroform/acetone $(1 / 1)$ for four minutes at $4^{\circ} \mathrm{C}$. Incubation with the first and subsequently with the second layer (goat anti-mouse Ig, fluorescein or rhodamine labelled, twice absorbed with human liver and affinity purified with human gammaglobulin (gift from Dr N Tidman)) was performed for 40 minutes. Incubation with an irrelevant monoclonal antibody (RF-HBs-1) which reacts with the ' $a$ ' determinant of $\mathrm{HBs} \mathrm{Ag}^{12}$ or the second layer alone was done as a control. Phosphate buffered saline (PBS) was used for washing steps.

IMMUNOFLUORESCENCE WITH ISOLATED HUMAN HEPATOCYTES AND HEPATOMA CELL LINE (PLC/ PRF/5).

Liver biopsies from patients with mild alcoholic liver disease were incubated with $2 \mathrm{ml}$ RPMI 1640 containing 1000 units collagenase (Worthington CLSP) and $0.2 \mathrm{ml}$ Trypsin inhibitor (Sigma) for 30 minutes at $37^{\circ} \mathrm{C}$ and teased with needles to release the cells. After washing in RPMI 1640 (containing $1 \%$ BSA) $20-30 \mu \mathrm{l}$ of the cell pellet (usually about $5 \times 10^{4}$ cells) were incubated with $200 \mu \mathrm{l}$ fresh culture supernatant for 45 minutes at room temperature, and subsequently with fluorescein labelled goat anti-mouse Ig (Dako) at a dilution 1/10 for 30 minutes. As a control, incubation with an irrelevant monoclonal antibody (RF-HBs-1) and the second layer alone, were done. Monolayer cultures of cells derived from a hepatoma cell line (PLC/ 
$\mathrm{PRF} / 5)^{13}$ grown in Eagle's minimum essential medium (Gibco) (supplemented with 10\% FCS, 2 $\mathrm{mM}$ glutamine, and antibiotics) were harvested with $2 \%$ EDTA (w/v) in PBS without $\mathrm{Ca}$ and $\mathrm{Mg}$. About $5 \times 10^{4}$ cells $(20 \mu \mathrm{l})$ were used for membrane staining as described for human hepatocytes.

\section{IODINATION OF ANTISERA}

Ten micrograms goat anti-mouse immune globulin $(5 \mu \mathrm{l})$ was iodinated with $0.5 \mathrm{mCi} \mathrm{I} \mathrm{I}^{125}$ using $10 \mu \mathrm{l}$ of chloramine $T(10 \mathrm{mg} / 10 \mathrm{ml})$ for 50 seconds on ice. The reaction was stopped by adding $50 \mu$ lyrosine ( 5 $\mathrm{mg} / 10 \mathrm{ml}$ ). Free iodine was removed by passing the mixture over a Dowex anion exchange column (Sigma) (bed volume $10 \times 1 \mathrm{~cm}$ ) in the presence of $200 \mu \mathrm{l}$ of a $10 \%$ solution of BSA, eluting with $1 \mathrm{~g} / 1$ BSA in Tris buffered saline ( $\mathrm{pH} \mathrm{8).} \mathrm{This} \mathrm{labelling}$ procedure resulted in an equimolar ratio of bound $\mathbf{I}^{125}$ to antibody protein and free iodine was less than $0 \cdot 1 \%$ of the total count.

For iodinating monoclonal antibodies $5 \mu \mathrm{g}$ protein-A purified antibody was allowed to react with $25 \mu \mathrm{g}$ chloramine $\mathrm{T}$ and $0.5 \mathrm{mCi}{ }^{125}$ for 30 seconds at $4^{\circ} \mathrm{C}$ in a total reaction volume of $15 \mu \mathrm{l}$. Subsequent procedures were performed as above.

\section{IMMUNOPRECIPITATION OF LIVER SPECIFIC} LIPOPROTEIN COMPONENT ANTIGENS WITH MONOCLONAL ANTIBODIES AND SDS-PAGE AUTORADIOGRAPHY

Forty micrograms $(100 \mu \mathrm{l})$ liver specific lipoprotein was labelled with $1 \mathrm{mCi} \mathrm{I}^{125}$ in $10 \mu \mathrm{g}$ Iodogen (Pierce Biochemicals) coated vials. ${ }^{14}$ After 15 minutes the reaction was stopped by adding $100 \mu \mathrm{l}$ $3 \%$ BSA buffer $(0.1 \mathrm{M}$ Tris- $\mathrm{HCl}, \mathrm{pH} 8 \cdot 1,0.4 \mathrm{M}$ $\mathrm{NaCl}, 1 \mathrm{mM}$ EDTA, 0.2 mM PMSF, buffer B) and transferring the mixture to a Sephadex G 100 column (10 $\mathrm{ml}$ syringe) equilibrated with the same buffer. The void volume peak (LSP-I ${ }^{125}$ ) was collected in $200 \mu$ l fractions.

LSP-I ${ }^{125}$ was pre-absorbed, with $100 \mu$ lof a $10 \%$ $(w / v)$ suspension (buffer B) of heat inactivated and formalin fixed Staphylococcus aureus (strain Cowan 1) at $4^{\circ} \mathrm{C}$ for one hour. Ninety microlitres absorbed LSP-I ${ }^{125}$ was incubated with $10 \mu \mathrm{l}, 100 \mu \mathrm{l}$ and $1 \mathrm{ml}$ respectively of culture supernatant containing antibodies overnight at $4^{\circ} \mathrm{C}$. Thirty microlitres of $10 \% S$ aureus (in some experiments coated with $5 \mu \mathrm{l}$ of $2 \mathrm{mg} / \mathrm{ml}$ goat antimouse- $\mathrm{Ig} / 30 \mu \mathrm{l} S$ aureus) was added $(30 \mathrm{~min})$ and the precipitate spun down at $16000 \mathrm{~g}$ for 45 minutes and washed three times in buffer B. After the third wash $30 \mu$ l of sample buffer (2\% SDS, $80 \mathrm{mM}$ Tric- $\mathrm{HCl}, \mathrm{pH} 6 \cdot 8,0 \cdot 1 \mathrm{M}$ DTT, $0 \cdot 2$ mM PMSF, $10 \%$ glycerol) were added. The samples were then boiled for five minutes and analysed by electrophoresis in a $10 \%$ polyacrylamide slab gel
$(10 \times 0.7 \times 12 \mathrm{~cm})$ using the Lammli system. ${ }^{15}$ Radiolabelled proteins were detected by autoradiography at $-70^{\circ} \mathrm{C}$.

\section{Results}

IMMUNISATION AND GENERATION OF HYBRIDOMA After three injections of $50 \mu \mathrm{g}$ liver specific lipoprotein ip there was a significant anti-liver specific lipoprotein response in all immunised mice as measured by radiometric binding assay. An example (mouse 2) is given in Figure 1. Out of four separate fusion attempts 13 antibody producing hybridomas were selected by criteria of immunofluorescence reaction pattern on human liver tissue. When testing these antibodies by radiometric binding assay using four different liver specific lipoprotein preparations only eight of them reacted with liver specific lipoprotein (Fig. 2). Further investigations concentrated on these antibodies (labelled RF-L1, 6, 8, 9, 10, 11, 12 and 13). All were of IgGI clas $s$.

IMMUNOFLUORESCENCE PATTERNS OF ANTI-LIVER SPECIFIC LIPOPROTEIN MONOCLONAL ANTIBODIES ON LIVER SECTIONS AND ISOLATED HEPATOCYTES The reaction pattern of the monoclonal antibodies on liver tissue sections and liver cell suspensions is described in Table 1. Monoclonal antibody 1 showed a very weak binding to liver specific lipoprotein but displayed a clear membrane staining of hepatocytes (Fig. 3a). Bile ducts and other

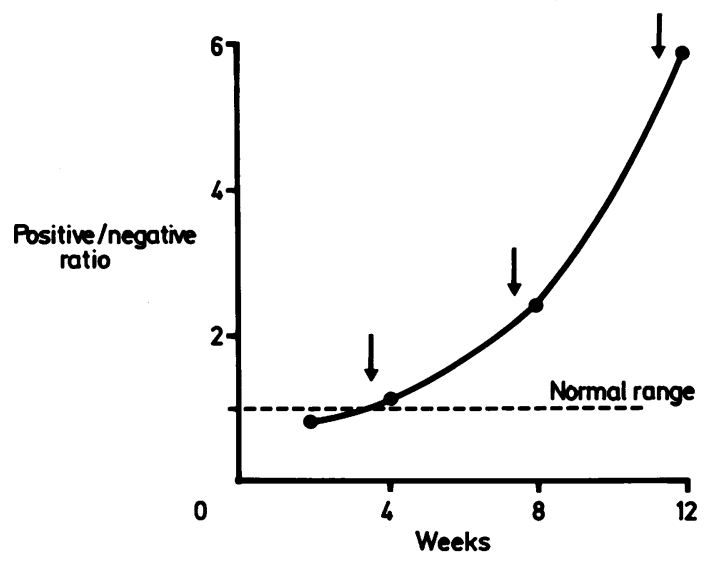

Fig. 1 Anti-liver specific lipoprotein response after immunisation ( $\downarrow$ ) of a Balb/c mouse with $50 \mu \mathrm{g}$ liver specific lipoprotein. The results are expressed as the ratio of counts bound in positive and negative mouse serum (dilution 1/5000). 


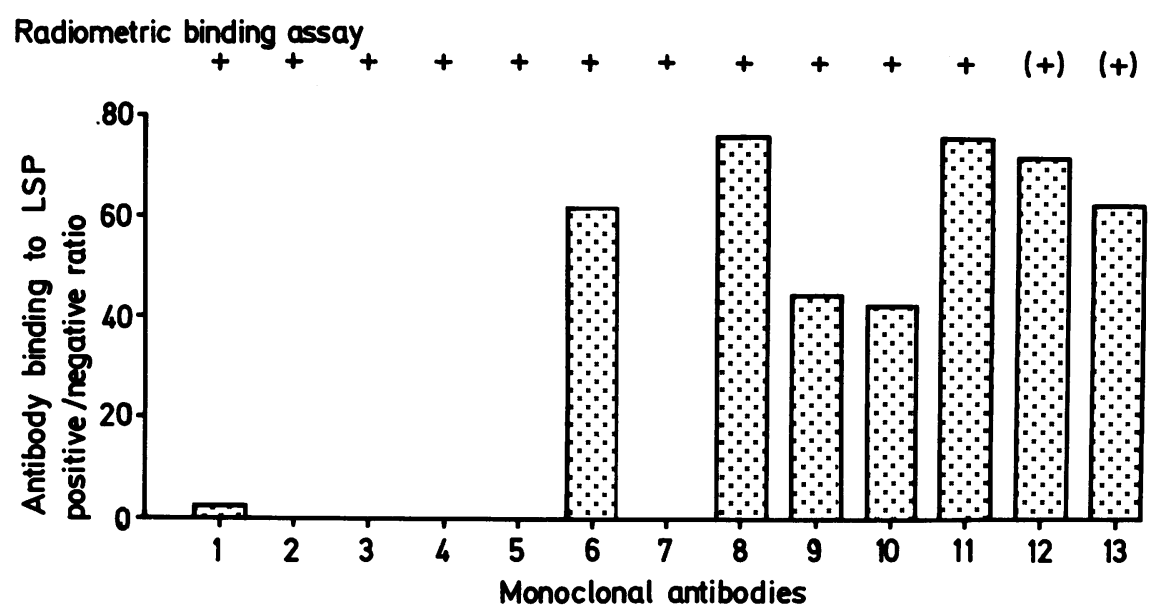

Fig. 2 Detection of monoclonal antibodies to liver specific lipoprotein: comparison between radiometric binding assay and immunofluorescence on liver tissues sections. Out of 13 antibodies showing a positive reaction along the hepatocyte membrane, sinusoidal wall or the hepatocyte cytoplasm in tissue sections, eight antibodies reacted with liver specific lipoprotein in a radiometric binding assay; $5 \mu \mathrm{g} / \mathrm{ml}$ antibody containing culture supernatant was used. + strong positive, (+) weak positive.

structures in the portal tract were negative. Antibodies 6 (Fig. 3b) 10 and 12 predominantly bound to the sinusoidal wall, with weak staining of the periphery of hepatocytes. Antibody 13 reacted strongly with liver specific lipoprotein but showed only a very faint patchy staining around the hepatocytes. Antibody 9 bound only to the sinusoidal wall (Fig. 3c). Antibodies 8 and 11 showed a strong cytoplasmic staining of hepatocytes (Fig. 3d).

When using isolated hepatocytes all antibodies except monoclonal antibody 9 showed a clear linear membrane staining. It should be noted that both antibodies reacting with liver cytoplasm also gave membrane staining of isolated human hepatocytes. Using a hepatoma cell line (PLC/PRF/5) monoclonal antibodies $1,6,8,9$ and 11 were negative.

\section{BLOCKING EXPERIMENTS}

Monoclonal antibodies 6,10 and 12, showing only a slight difference of immunofluorescence pattern on liver tissue sections, as well as 8 and 11 , both with a cytoplasmic labelling pattern of hepatocytes were used in a blocking assay. No blocking was observed between monoclonal antibodies 6,10 and 12 and between 8 and 11 . Also no enhancement of antibody activity could be observed during these experiments.

Table 1 Monoclonal antibodies to liver specific lipoprotein: immunofluorescence pattern on liver tissue sections and reaction with cell membranes of normal human hepatocytes and hepatoma cells (PLC/PRF/5)

\begin{tabular}{llll}
\hline & & Membrane staining of \\
\cline { 3 - 4 } Monoclonal antibodies & Staining of liver tissue sections & Isolated human hepatocytes & Hepatoma cell line \\
\hline 1 & Membrane of hepatocytes + & + & - \\
6 & Sinusoidal wall,+ hepatocyte membrane $(+)$ & + & + \\
8 & Cytoplasm + & $(+)$ & - \\
9 & Sinusoidal wall, + & - & - \\
10 & Sinusoidal wall +, hepatocyte membrane (+) & + & + \\
11 & Cytoplasm + & + & + \\
12 & Sinusoidal wall + , hepatocyte membrane $(+)$ & + & + \\
13 & Patches around hepatocytes $(+)$ & + & + \\
\hline
\end{tabular}

+ strong positive; $(+)$ weakly positive; - negative. 

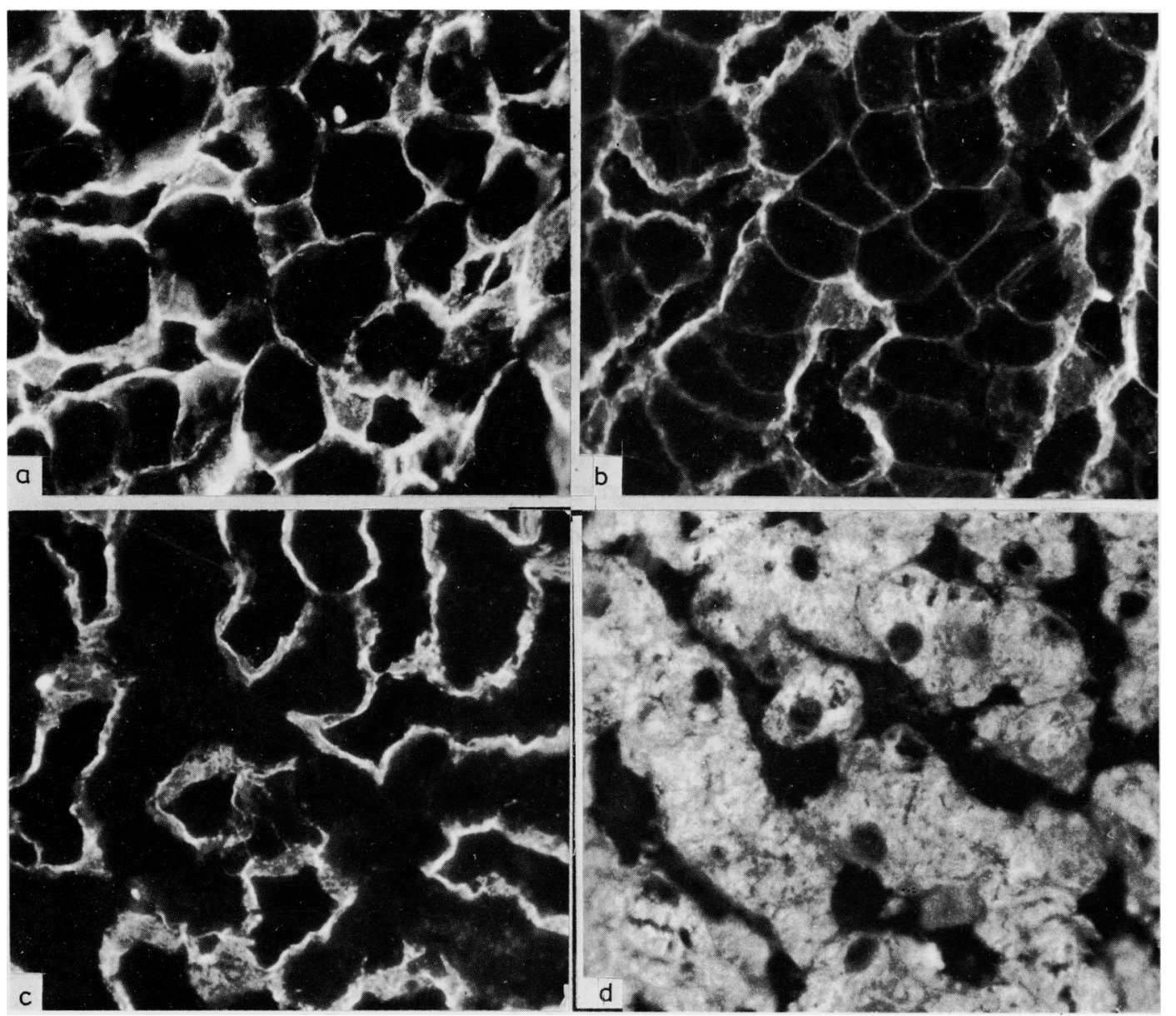

Fig. 3 a-d Immunofluorescence reaction pattern of monoclonal antibodies to liver specific lipoprotein on liver tissue cryostat sections ( $\times 50$ objective). Mcl Abl reacted strongly at the periphery of hepatocytes (Fig. $3 a$ ). Mcl Ab6 ( $3 b$ ) showed a weaker hepatocyte membrane and a pronounced sinusoidal wall labelling. Mcl Ab9 (3c) reacted exclusively with the sinusoidal wall. Mcl Ab8 (3d) stained the liver cell cytoplasm sparing the nuclei and was negative on the sinusoidal lining cells.

CROSS-REACTIVITY OF MONOCLONAL ANTIBODIES WITH VARIOUS TISSUES OF SEVERAL SPECIES

The reaction of antibodies was not restricted to liver tissue as shown in Table 2. There was a cross reaction either with parenchymal cells of other organs, (particularly kidney) including blood vessels or tissue matrix structures.

Monoclonal antibodies 6,8 and 12 were also positive when rabbit sections or tissue homogenates were used for testing. Monoclonal antibodies 1, 9, 10,11 and 13 reacted only with human tissues.

REACTION OF MONOCLONAL ANTIBODIES WITH VARIOUS DETERMINANTS OF LIVER SPECIFIC
LIPOPROTEIN: DETERMINATION OF MOLECULAR WEIGHT

Using the immune precipitation technique it was possible to determine the molecular weight of four liver specific lipoprotein antigens recognised by monoclonal antibodies 8, 9, 11 and 12 (Fig. 4). The molecular weight range was from $164 \mathrm{~K}$ to $22 \mathrm{~K}$. The antigens precipitated by monoclonal antibodies 9 and 12 each displayed two bands in the autoradiograph. Various modifications of the technique - that is, using goat anti-mouse Ig coated $S$ aureus and using detergents - did not lead to a successful precipitation of the proteins reacting with the remaining four antibodies. 
Table 2 Immunofluorescence reaction of monoclonal antibodies against liver specific lipoprotein on various human tissues

\begin{tabular}{|c|c|c|c|c|c|c|c|c|c|c|c|}
\hline \multirow[b]{2}{*}{$\begin{array}{l}\text { Monoclonal } \\
\text { antibody }\end{array}$} & \multirow[b]{2}{*}{ Liver } & \multirow[b]{2}{*}{$\begin{array}{l}\text { Gut } \\
\text { epithelium }\end{array}$} & \multirow[b]{2}{*}{$\begin{array}{l}\text { Pancreatic } \\
\text { acini }\end{array}$} & \multirow[b]{2}{*}{$\begin{array}{l}\text { Kidney } \\
\text { tubules }\end{array}$} & \multirow[b]{2}{*}{ Thyroid } & \multirow{2}{*}{$\begin{array}{l}\text { Tonsil } \\
\text { lympho- } \\
\text { cytes }\end{array}$} & \multirow{2}{*}{$\begin{array}{l}\text { Skeletal } \\
\text { muscle } \\
\text { cells }\end{array}$} & \multirow[b]{2}{*}{$\begin{array}{l}\text { Skin } \\
\text { epithelium }\end{array}$} & \multicolumn{2}{|l|}{ Blood vessel } & \multirow[b]{2}{*}{$\begin{array}{l}\text { Tissue } \\
\text { matrix }\end{array}$} \\
\hline & & & & & & & & & $\begin{array}{l}\text { Vascular } \\
\text { endothelium }\end{array}$ & $\begin{array}{l}\text { Sub- } \\
\text { endothelial }\end{array}$ & \\
\hline 1 & + & + & - & + & - & - & - & - & - & - & - \\
\hline 6 & + & - & - & - & - & - & NT & - & - & + & - \\
\hline 8 & + & + & $(+)$ & + & $(+)$ & + & + & - & + & - & - \\
\hline 9 & + & - & - & - & - & - & - & - & - & + & + \\
\hline 10 & + & - & - & - & - & - & - & - & - & + & - \\
\hline 11 & + & + & + & + & + & + & + & - & + & - & - \\
\hline 12 & + & - & - & - & - & - & - & - & - & + & - \\
\hline $13^{*}$ & $(+)$ & + & NT & $(+)$ & NT & + & NT & NT & NT & NT & NT \\
\hline
\end{tabular}

* Test was performed using tissue homogenates in a radiometric binding assay.

+ strong positive; (+) weakly positive; - negative; NT not tested.

\section{Discussion}

The antigenic composition of 'liver specific lipoprotein' prepared from human liver according to McFarlane et $\mathrm{al}^{3}$ has been analysed by raising a series of murine monoclonal antibodies. These reacted with determinants displayed on human liver sections, but only eight antibodies showed a constant binding to several liver specific lipoprotein preparations. Several reasons may account for this observation. Presumably some of the antibodies

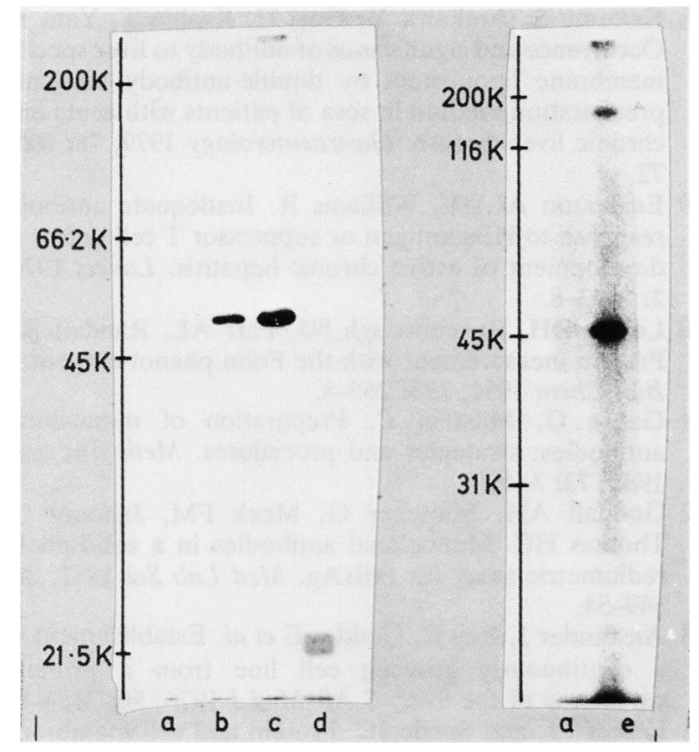

Fig. 4 Immunoprecipitation of liver specific lipoprotein antigens by monoclonal antibodies. RFL $8(b), R F-L-11$ (c), RF-L-9 (d) and RF-L-12 (e). Control (a) with the irrelevant monoclonal antibody RF-HBs-1. were raised against quantitatively minor components of the liver specific lipoprotein preparation which are present in higher concentrations in the native tissue. Such epitopes are either partially destroyed during the extraction process or the molecules bearing them do not adhere to the microtitre plate. Alternatively, they were produced against labile components of the liver specific lipoprotein preparations which were not present several weeks later when the antibodies were tested on the stored liver specific lipoprotein.

The eight anti-liver specific lipoprotein monoclonal antibodies further characterised in this study each reacted with different epitopes of the complex as shown by different immunofluorescence reaction patterns on liver sections and/or by competitive inhibition experiments. Four of them reacted with proteins of MW between 22 and 164 KD. Analysis of the distribution of liver specific lipoprotein determinants on human liver tissue sections revealed that they are localised around the hepatocytes and/or along the sinusoidal cells. Furthermore, the liver cytoplasmic labelling pattern of two antibodies clearly indicated that liver specific lipoprotein preparations also contain cytoplasmic antigens. By demonstrating binding of seven of the eight antibodies to viable human hepatocytes, a membranous localisation of most of the liver specific lipoprotein antigens defined here could be confirmed - an observation which has been made with polyclonal rabbit anti-liver specific lipoprotein. ${ }^{2} 3$ In human sera, however, the presence of anti-liver specific lipoprotein measured by RIA did not correlate ${ }^{5}$ with the presence of liver membrane antibodies binding to rabbit hepatocytes ${ }^{16}$ suggesting that some of the antibodies to liver specific lipoprotein may be species specific, binding only to determinants found on human and not on rabbit hepatocytes, or to cryptic 
determinants not 'seen' on the intact hepatocyte. ${ }^{17}$ The existence of species specific and non-specific liver specific lipoprotein determinants has been reported earlier ${ }^{15}$ and is supported by this study.

In contrast, the existence of a human liver specific determinant could not be shown in this study, confirming the work of other authors who failed to show liver specific antibodies when rabbits.were immunised with liver specific lipoprotein. ${ }^{18} \mathrm{~A}$ monoclonal antibody was, however, recently reported to react with a liver specific component from rabbit liver specific lipoprotein. ${ }^{19}$ Whether such determinants also exist in human liver specific lipoprotein will require the production of a larger library of antibodies. The crossreactivity of antibodies reported here included various tissues especially kidney confirming that many liver specific lipoprotein determinants are shared by kidney antigens. ${ }^{18} 20$ The demonstration that liver specific lipoprotein contains numerous non-liver determinants raises problems when this antigen complex is used to analyse sera for liver-specific antibodies and peripheral blood lymphocytes for sensitisation to liver-specific antigens. These systems will detect sensitisation to non-liver specific determinants and the relevance of the reactions to liver injury is therefore difficult to establish. Immune responses to determinants, however, shared between the liver and other tissues may be the basis for the multisystemic distribution of lesions in patients with chronic hepatitis. For example, the demonstration of antigenic cross-reactivity of liver proteins with Tamm Horsfall proteins may explain the association of renal tubular acidosis with autoimmune chronic liver disease. ${ }^{21}$

In this study, we have started to map the epitope display on the liver specific lipoprotein complex and have failed to confirm liver specificity. Whether any of these epitopes are the target of the autoantibodies responsible for liver damage has yet to be determined. Further identification of the epitope specificity of these autoantibodies using the techniques applied in this study is the first step in divising methods for regulation of this abnormal immune response by anti-idiotype or clonal deletion approaches.

We are grateful to Mr Kirk, Mr O Fernando, and M Bonfil for providing us with human tissues. Rhodamine conjugated goat anti-mouse immunoglobulin was a kind gift from $\mathrm{N}$ Tidman.

KHW is supported by the Deutsche Forschungsgemeinschaft, Bonn, Wi $6481-1$. HCT is a Senior Wellcome Fellow in Clinical Science.

\section{References}

1 Meyer zum Büschenfelde KH, Miescher PA. Liver specific antigens. Purification and characterisation. Clin Exp Immunol 1972; 10: 89-102.

2 Hopf U, Meyer zum Büschenfelde KH, Freudenderg J. Liver-specific antigens of different species. II Localisation of a membrane antigen at cell surface of isolated hepatocytes. Clin Exp Immunol 1974; 16: $117-24$.

3 McFarlane IG, Wojcicka BM, Zucker GM, Eddleston ALWF. Purification and characterisation of human liver specific membrane lipoprotein (LSP). Clin Exp Immunol 1977; 27: 381-90.

4 Manns M, Meyer zum Büschenfelde KH, Hütteroth $\mathrm{TH}$, Hopf $\mathrm{U}$. The liver specific protein: evidence for species specific and non-species specific determinants. J Clin Lab Immunol 1980; 3: 9-14.

5 Manns M, Meyer zum Büschenfelde KH, Hess G. Autoantibodies against liver-specific membrane lipoprotein in acute and chronic liver diseases: studies on organ-, species-, and disease-specificity. Gut 1980; 21: $955-61$.

6 Miller J, Smith MGM, Mitchell CG, Reed WD, Eddleston ALWF, Williams R. Cell mediated immunity to a human liver-specific antigen in patients with active chronic hepatitis and primary biliary cirrhosis. Lancet 1972; 2: 296-7.

7 Jensen DM, McFarlane IG, Portmann BS, Eddleston DM, Williams R. Detection of antibodies directed against a liver-specific membrane lipoprotein in patients with acute and chronic active hepatitis. $N$ Engl J Med 1978; 299: 1-7.

8 Kakumu S, Arakawa Y, Gojj H, Kashio T, Yata K. Occurrence and significance of antibody to liver specific membrane lipoprotein by double-antibody immunoprecipitation method in sera of patients with acute and chronic liver disease. Gastroenterology 1979; 76: 66572.

9 Eddleston ALWF, Williams R. Inadequate antibody response to HBs antigen or suppressor $\mathrm{T}$ cell defect in development of active chronic hepatitis. Lancet 1974; 2: 1543-8.

10 Lowry OH, Rosenbrough NJ, Farr AL, Randall RJ. Protein measurement with the Folin phenol reagent. $J$ Biol Chem 1951; 193: 265-8.

11 Galfre G, Milstein C. Preparation of monoclonal antibodies: strategies and procedures. Meth Enzymol 1981; 73: 3-46.

12 Goodall AH, Miescher G, Meek FM, Janossy G, Thomas HC. Monoclonal antibodies in a solid-phase radiometric assay for $\mathrm{HBsAg}$. Med Lab Sci 1981; 38: $349-54$.

13 Alexander J, Bey E, Geddes E et al. Establishment of a continuously growing cell line from a primary carcinoma of the liver. S Afr Med J 1976; 50: 2124-8.

14 Fraker PJ, and Spede JC. Protein and cell membrane iodination with a sparingly soluble chloroamide $1,3,4,6$ Tetrachloro-3, 6-diphenzlglycourin. Biochem Biophys Res Commun 1978; 80: 849-57.

15 Lämmli K. Cleavage of structural proteins during the assembly of the heads of bacteriophage T4. Nature 
(Lond) 1970; 227: 680-5.

16 Hopf U, Meyer zum Büschenfelde KH, Arnold W. Detection of a liver membrane autoantibody in HBsAg-negative chronic active hepatitis. $N$ Engl J Med 1976; 294: 578-82.

17 Wiedmann KH, Bartholomew TC, Brown DJC, Thomas HC. Liver membrane antibodies detected by immunoradiometric assay in acute and chronic virus induced and autoimmune liver disease. Hepatology 1984; 4: 199-204.

18 Behrens KJ, Paronetto F. Studies on liver specific antigens I. Evaluation of the liver specificity of "LSP" and LP-2. Gastroenterology 1979; 77: 1045-52.

19 Poralla T, Dippold W, Dienes HP, Manns M, Meyer zum Büschenfelde $\mathrm{KH}$. A monoclonal antibody directed against an organ-specific liver cell membrane antigen in rabbits. $J$ Immunol Meth 1984; 68: 341-8.

20 Behrens KJ, Vernace S, Paronetto F. Studies on 'liver-specific' antigens II. Detection of serum antibodies to liver and kidney cell membrane antigens in patients with chronic liver disease. Gastroenterology 1979; 77: 1053-61.

21 Tsantoulas DC, McFarlane IG, Portmann B et al. Cell mediated immunity to human Tamm-Horsfall glycoprotein in autoimmune liver disease with renal tubular acidosis. Br Med J 1974; 4: 491-4. 